\title{
Проблемы исполнительства
}

\section{Александр МЕРКУЛОВ}

\section{МИМИКА И ЖЕСТИКУЛЯЦИЯ ПИАНИСТА В СИСТЕМЕ ИСПОЛНИТЕЛЬСКИХ ВЫРАЗИТЕЛЬНЫХ СРЕДСТВ}

Часто педагоги - слушатели курсов ФПК в высших учебных заведениях и учебно-методических центрах, а также студенты и аспиранты на лекџиях по методике задают вопросы, касающиеся внешней стороны игры исполнителя, пластики его движений, манеры сџенического поведения за инструментом. Как правило, педагогов настораживает, когда их подопечные ведут себя за роялем развязно, когда они раскачиваются, чересчур размахивают руками, гримасничают. Студенты же часто жалуются на своих профессоров, которые якобы слишком строги в отношении пантомимических действий.

Спеџиальных исследовательских работ на эту тему нет, и музыкантам неоткуда почерпнуть столь необходимую им информацию. «Представители некоторых исполнительских школ, - указывал

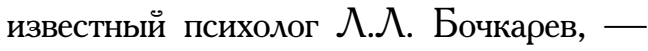
очень скупы на внешнее выражение эмоџй̈ средствами мимики, пантомимики, считая последние проявлением антимузыкальности» [5, с. 127]. Другие, наоборот, считают исполнение немузыкальным или недостаточно музыкаль- ным, если пианист или скрипач внешне скован, инертен, статуарен, не выражает пластическими средствами содержание музыки, играет, например, скерџозную музыку с унылым, постным, безразличным выражением лиџа.

Один из знакомых педагогов как-то назвал эту тему «мутной» и не советовал в нее углубляться. Более того, ряд колег - и практиков, и историков пианизма - считают, что данной проблемы как таковой не существует: «Надо просто играть и не думать ни о чем постороннем». И это при том, что период рубежа XX-XXI веков ознаменован, по общему мнению, резкой визуализацей сознания - вплоть до массового укоренения «клипового мышления» (нельзя забывать и того, что в обыденной жизни человек получает 90\% информађии посредством зрения). Широкое распространение в последние годы в повседневном музыкальном обиходе видеофильмов об исполнителях, видеозаписей и телетрансляџий конџертов вызывает повышенное внимание к пантомимической стороне игры (в том числе благо- 
даря использованию «крупного плана» при показе рук и лиџа артиста). Все это делает обрисованную проблему особенно актуальной и злободневной, а ее научное изучение - весьма насущным.

\section{$* * *$}

Нельзя сказать, что о важности зрительных впечатлений в восприятии игры пианистов (равно как и исполнителей на других инструментах) вовсе никогда не говорилось. Наблюдений, и весьма прониџательных, имеется немало, хотя они (в силу их разбросанности по разным источникам) не систематизированы, крайне мало известны и почти не востребованы.

Можно указать, в частности, на мнение, высказанное однажды 人.Н. Власенко: «Когда я вижу исполнителя, мне становится понятнее его искусство: жесты, позы, манера игры, мимика - все это несет в себе большую и важную информаџию» [џит. по: 31, с. 44]. Известный австрийский пианист-педагог Эдвин Фишер в 1956 году остроумно писал: «Мы в конџерте слушаем и глазами» [29, с. 169]. В декабре 2013 года

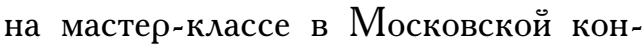
серватории почти те же самые слова произнес Д.А. Башкиров.

В 1961 году С.И. Савшинский отмечал «значение синтетичности восприятия слышимого и зримого в игре артиста со сџены» [26, с. 104]. А в 1988 году Г.М. Џыпин справед- ливо указывал, говоря о комплексном характере впечатлений посетителя концертов: «入юди приходят в конџертный зал не только чтобы yслышиать, но и увидеть артиста; восприятие в этом случае полнее, красочнее, эмоџионально богаче» [31, с. 24]. При этом исследователь констатировал также, что «внешность художника связана не только с его внутренним миром, но и - самое любопытное! с его индивидуальным творческим стилем, манерой, обшим характером художественной деятельности... С точки зрения психологической науки, тут много интересного, хотя пока и не совсем ясного...» [там же, с. 21-22].

Для того, чтобы немного разобраться в ситуаџии, думается, следует прежде всего, обратиться к истории фортепианного искусства.

Сила визуального воздействия крупной артистической личности отмечалась издавна. Еше Шуман, слушая Шопена, писал в 1836 году: «Трогательно наблюдать - как он сидит за роялем» [35, с. 265]. Восхитительно листовское описание внешности и манер Шопена: «Весь его облик напоминал џветок вьюнка, покачивающй на необычайно тонком стебле венчики чудесной расџветки - из такой благоуханної и нежной ткани, что рвется при малейшем проникновении... Жесты были изящны и выразительны... Он был неистошимо изобретателен в потешной пантомиме. Он забавлялся часто 
воспроизведением в своих комических импровизајиях музыкальных оборотов и приемов некоторых виртуозов, имитировал их жесты и движения, выражение лиџа - с талантом, вскрываюшим в одно мгновение всю их личность» [15, с. $247-248]$.

По поводу игры Аиста Шуман указывал в письме к Кларе Вик, а затем и в своей статье о Трансџендентных этюдах великого венгра: «Надо не только сльциать, но и видеть композитора [т. е. Листа]. Ибо если созерцание всякой виртуозности возвышает и укрепляет, то прежде всего в его непосредственной форме, когда мы видим, как сам композитор борется со своим инструментом, укрошает его, заставляет его повиноваться в каждом звуке» [34, с. 172]. В другом месте Шуман писал еще более определенно: «Слушая 入иста, его надо и видеть: он ни в коем случае не должен играть за кулисами, значительная часть поэзии (!) была бы при этом потеряна» [33, с. 235].

Знаменательно, что многие современники 入иста обрашали внимание на то, как он выглядит за инструментом. Желая лучше познакомить с ним слушателей, Мендельсон организовал для него в Лейпџиге большой раут, чтобы «дать людям возможность увидеть и усльшиать его вблизи» [35, с. 385]. Клара Вик писала Шуману в 1838 году: «Мы слышали Аиста. Его нельзя сравнить ни с одним пианистом... Как он выглядит за инструмен-

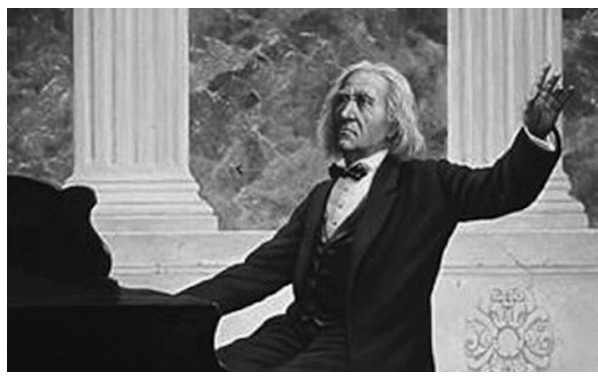

Уже один вид ФD. Листа на эстраде приковывал внимание

том описать невозможно... Его страсть не знает граниџ... Его движения неразрывно связаны с его игрой и очень подходят к нему. Он увлекает всякого в свой мир...» [там же, с. 631]. Лина Раман указывала, что, играя эпизоды монументального характера, 入ист возвышался над клавиатурой «как скала, выраставшая сверху» [џит. по: 17, с. 129], а Карл Клиндворт свидетельствовал, что «в торжественных и мошных пассажах, в crescendo, вызывавшем в представлении могушество урагана, все его сушество как бы становилось на дыбы» [џит. по: 17, с. 129-130].

Обобшая обширную фактологию, А.Д. Алексеев констатировал: «Уже один вид (!) Листа на әстраде приковывал внимание. Это был страстный, вдохновенный оратор. В него, вспоминают современники, словно вселялся дух, преображавший внешность пианиста: глаза горели, волосы трепетали, лиџо приобретало удивительное выражение» [3, с. 136].

A.E. Будяковский, пересказывая впечатления современников от внеш- 


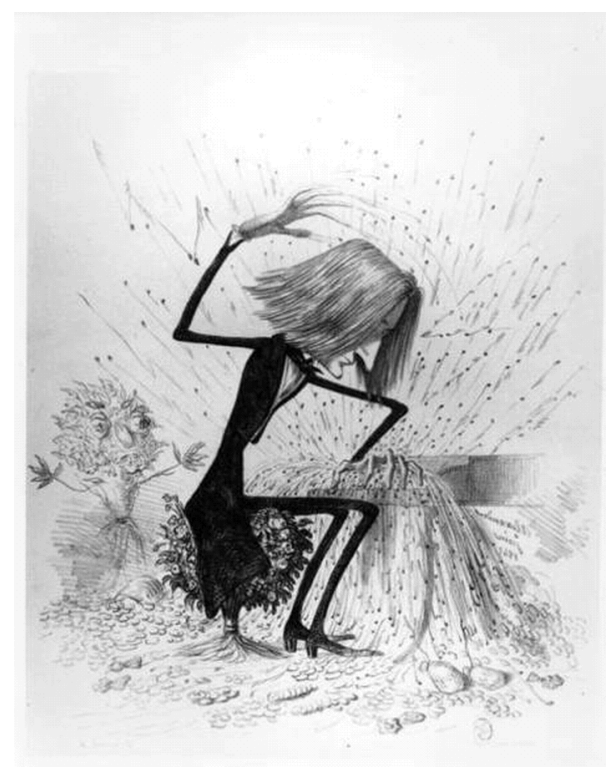

Иrраeт CD. Аucm (карикатура XIX в.)

него облика Листа на сџене, отмечал: «Артист быстро выходил, поспешно кланялся и “не садился, а кидался к фортепиано”... Играл обычно с большим возбуждением. Бывал чрезвычайно подвижен, а тонкие руки энергично выбрасывались и откидывались. Голова часто запрокидывалась назад. Привычный жест - отбрасывание волос во время игры (в Петербурге и Москве находили сходство Листа с Гоголем). РОль мимики огромна. Даже по одному только лиџу (!) можно было судить о характере исполняемого им произведения» [6, с. 32].

В том же ключе об огромном впечатлении уже от самой внешности А.Г. Рубинштейна писали
П.И. Чайковский и русский фортепианный педагог-методист М.Н. Курбатов. Петр Ильич отмечал: «Я имел случай слышать Рубинштейна и не только слышать, но и видеть (подчеркнуто Чайковским. - . М.)... Я подчеркиваю это первое впечатление чувства зрения (!) потому, что, по моему глубокому убеждению, престиж Рубинштейна основан не только на его несравненном таланте, а также на непобедимом очаровании его личности, так что недостаточно его сльшать для полноты впечатления - надо также его видеть» [џит. по: 26, с. 103]. Перефразируя отмеченную мысль Чайковского

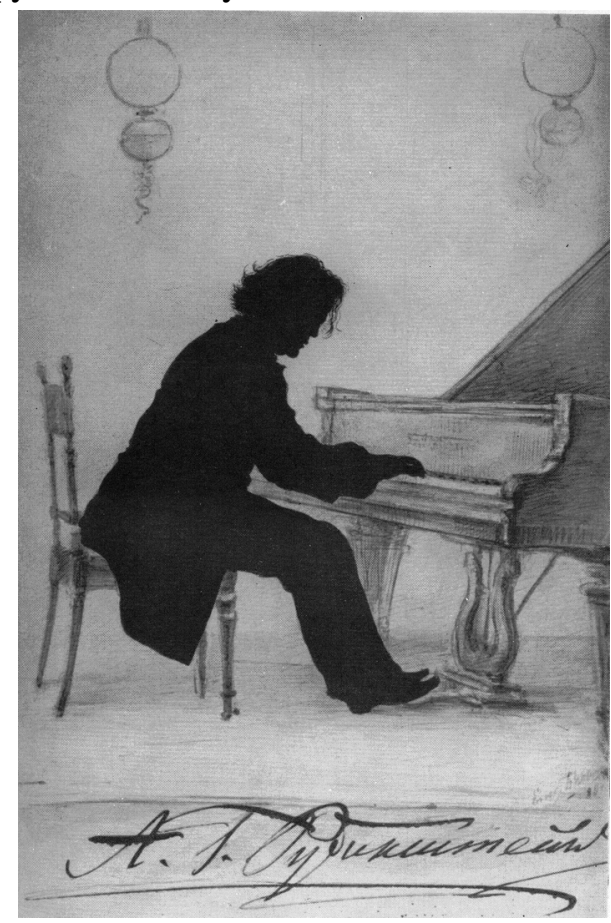

A. Рубинштейн за роялем (рисунок работы Е. Бём, нач. 1870-х) 
о Рубинштейне, Л.А. Баренбойм полностью относил ее и к восприятию пианистического искусства Э.Г. Гилельса.

В связи с особенностями сильнейшего воздействия названных великих артистов-романтиков на публику неслучайно обилие карикатур на выступления и Листа, и Рубинштейна, и (если выйти за пределы фортепианного искусства) Паганини. Неслучайны и сравнения Листа с орлом, Рубинштейна со львом и т. д. Неслучайны и неоднократные упоминания «могучей львиной лапы»

Правда, в то же самое время ряд выдаюшихся пианистов придерживался противоположной манеры поведения на сџене. Знаменитый соперник $\mathrm{CD}_{\text {ран- }}$ џа Листа - Сигизмунд Тальберг опирался в своей исполнительской эстетике на некоторые полярные по отношению к автору «Венгерских рапсодий» принџипы. Если Лист максимально использовал динамические контрасты фортепиано и, по выражению Клары Шуман, «то кричал, то шептал за роялем», то Тальберг, наоборот, намеренно держался «золотой середины», избегая звуковых крайностей. Внешне он тоже был полной противоположностью Листа. По наблюдению Игнаџа Мошелеса, «Тальберг за инструментом напоминал солдата, губы которого были плотно сжаты, а сюртук застегнут на все пуговиџы» [џит. по: 32, c. 170]. «От коллег по роялю этот артист выгодно отличается, я бы сказал, музыкальным поведением, - писал Генрих Гейне. - Как в жизни, так и в своем искусстве Тальберг проявляет врожденный такт; игра его такая джентльменская, она так богата, так благопристойна, так чужда всяких гримас, так чужда надутого гениальничания, так чужда глупой хвастливости... Его любят, хотя он не вызывает сострадания эпилептическими припадками на фортепиано» [10, с. 210]. Противоположность творческих натур выдаюшихся пианистов подчеркивал тот же Гейне: «Благородный, полный чувства, рассудительный, добродушный, тихий, чисто немеџкий, даже австрийский Тальберг и необузданный, молниеносный, вулканический и ни перед чем не останавливаюшийся Лист!» [џит. по: 6, с. 29].

Такая же, как у Тальберга, аскетическая манера поведения на конџертной эстраде отличала Джона СФильда с его, по свидетельству Листа, «почти неподвижной позой и безучастным выражением лица». СОильд, обладатель «льстивого», по выражению Б.Л. Яворского, туше, в свою очередь, резко критиковал Листа, «составлявшего с ним самим поразительнейший контраст» (слова А.И. Дюбюка). Как пояснял Дюбюк, после одного из выступлений молодого Листа, «насмотревшись на смелые кидки рук и удары со всего размаха, наслушавшись громоносных звуков, столь чуждых его собственной школе, С Иильд обратился 
к присутствовавшим с вопросом: “А что, он не кусается”?» [џит. по: 11, с. 116].

Еше одной противоположностью 入исту был Фридрих Калькбреннер (у него мечтал учиться юный Шопен), которого, по словам Гейне, отличали «марџипанный облик», «элегантная осанка» и на губах которого блестела «та набальзамированная улыбка, которую мы заметили также на лиџе египетского фараона, когда в музее развернули его мумию...» [10, с. 208].

Не любил игру Листа и известнё̈ший венскиї критик Эдуард Ганслик. Не без иронии он определял его выступления как «театр 入иста». Другой известный критик того времени также резко осуждал «актерство» Листа: «C шумом усаживаясь за фортепиано, он окидывает публику ястребиным взглядом, кладет руки на клавиши, а затем мечет громы и молнии и при этом имеет еще достаточно хладнокровия, чтобы наблюдать производимый на публику әффект» [џит. по: 14, c. 117].

Различия во внешних обликах четырех крупнейших пианистов тех лет, гастролировавших в Вене в 1838 году, - Тальберга, Клары Вик (Шуман), Адольфа Гензельта и Аиста зафиксировал в своих сравнительных характеристиках профессор Венской консерватории и ее директор, пианист-педагог и композитор Йозеф Фишгоф. В письме к Роберту Шуману он сопоставлял их игру по многим ком- понентам, в том числе пантомимическим, и коротко констатировал: «Без гримас во время игры - 1. Тальберг. 2. Клара» [џит. по: 6, с. 34].

Впрочем, разные стили держать себя за инструментом во время игры можно обнаружить и в более отдаленные времена.

Знаменитый английский музыкант и путешественник Чарльз Бёрни так описывал игру К.Ф.Э. Баха в 1772 году: «После обеда я уговорил его снова сесть за клавикорд, и он играл почти до одиннадџати часов ночи. В течение этого времени он становился столь взволнованным и одержимьм, что не только играл вдохновенно, но и выглядел так. Его глаза были неподвижны, губа отвисла, а по лиџу катились капли пота... Его исполнение убедило меня в том, что он не только один из величайших композиторов, когда-либо сочинявших для клавишных инструментов, но и лучший исполнитель с точки зрения выражения (везде выделено Бёрни. - $A . M)$. [4, с. 235]. Современник Карла Филиппа Эмануэля Баха — Ф.В. Марпург, именно его имея в виду, еще в 1749 году писал: «Я знаю одного великого композитора, на лиџе которого (!) можно увидеть все, что выражает музыка, исполняемая им на клавире» [36, с. 103] (слова эти, кстати, можно полностью отнести и к Листу).

Сам берлинский Бах писал в своем трактате в 1753 году: «Музыкант 
может растрогать слушателей только в том случае, когда будет растроган сам... При музыке томной и печальной он сам делается томным и печальным - это и слышно, и видно (!) по нему. Таким же образом он переносится в музыку бурную, веселую или какого-либо иного характера... Однако сильнее всего клавирист может захватить слушателей импровизаџией фантазии. При этом без мимики (!) нельзя обойтись - это может отриџать только тот, кто, будучи бесчувственным, сидит за инструментом, как изваяние. Насколько неприлична и вредна для исполнения безобразная мимика, настолько же полезна хорошая, ибо помогает (!) передать слушателю наши намерения» [џит. по: 2, с. 48-49].

Описанная манера игры Эмануэля Баха удивительно сходна с характером волеизъявления за роялем необычайно эмоџионального Бетховена, испытавшего сильное влияние творчества берлинского Баха. Очевидеџ сообщал: «Когда Бетховен сидел за роялем, он явно не воспринимал ничего окружающего... Мускулы его лиџа напрягались, и вены набухали, безумный глаз вращался еще более безумно, губы дрожали; Бетховен выглядел, как чародей, охваченный демонами, которых он сам вызывал» [32, с. 86].

Значительно ранее - в 1670-х годах (задолго до Паганини и Листа!) сверхэмоџиональную, гиперромантичную манеру игры демонстрировал
Арканджело Корелли. Свидетель его выступления констатировал: «Я никогда не видел человека, который вкладывал бы столько страсти и увлечения в свою игру. Глаза его сверкали, подобно искрам, черты лиџа так искажались, глазные яблоки вращались как в агонии, и весь он настолько отдавался тому, что делал, что становился непохожим на самого себя» [џит. по: 12, с. 70].

Но нельзя думать, что все музыканты - современники А. Корелли или К.Ф.Э. Баха - придерживались такого подхода. Многие исповедовали принципы, изложенные в 1716 году Франсуа Купереном в его «Искусстве игры на клавесине». Куперен Великиї наставлял: «За клавесином надо сидеть непринужденно; взгляд не должен быть ни сосредоточенным на какомлибо предмете, ни рассеянным; словом, надо выглядеть так, будто ты ничем не занят... Не следует отмечать такта ни голової, ни корпусом, ни ногої это и лучше, и приличнее... Избавиться от гримас на лиџе при игре можно самому, без постороннего содействия, с помощью зеркала, поставленного на пюпитр спинета или клавесина» [13, с. 14]. В середине $\mathrm{XX}$ столетия то же средство от гримас за роялем рекомендовал Артуро Бенедетти Микеланджели, державшийся за инструментом, судя по сохранившимся видеозаписям, весьма отстраненно, чопорно и аристократично. (Совсем не случайно, не без определенного подтекста Г.Г. Нейгауз 
писал, что искусство итальянского музыканта «напоминает мраморное изваяние» [21, с. 296]).

В 1853 году в книге «Фортепиано и пение» Фридрих Вик, отеџ Клары Шуман, обрушивал свой гнев против «рояльных плясунов», косвенно отмечая полярность исполнительских установок его времени: «Многие виртуозы, одержимые фортепианными фуриями, играют большую бравурную пьесу, ужасно гримасничают, свирепо гоняют пассажи... лупят... рвут струны... потеют, откидывают волосы с лиџа, строят глазки публике» [8, с. 263].

Можно вспомнить в данном контексте венского пианиста Теодора Делера, которого в реџензии 1844 года следующим образом противопоставляли 入исту: «Первый, подобно нежному и лучезарному ангелу, реет в пространстве. Второй, как яростный и грозный демон, грохочет, подобно подземному грому. Делер не ищет оригинальности и эффектов, подобно божеству, он обуздывает свои фантазии и ласкает звуки, как отеџ ласкает сына. Лист, наоборот, хлещет их, как кучер хлещет лошадей, мучит, как деспот мучит своих рабов. Опьяненный энтузиазмом, он терзает инструмент, рвет струны и, сгушая контрасты красок, создает новые, но резкие и странные комбинаџии. Делер возвышает душу, оживляет и очищает ее; 入ист волнует кровь, бьет по нервам, вливает в вены опьяняющий напиток, вызывающий искусственную мощь

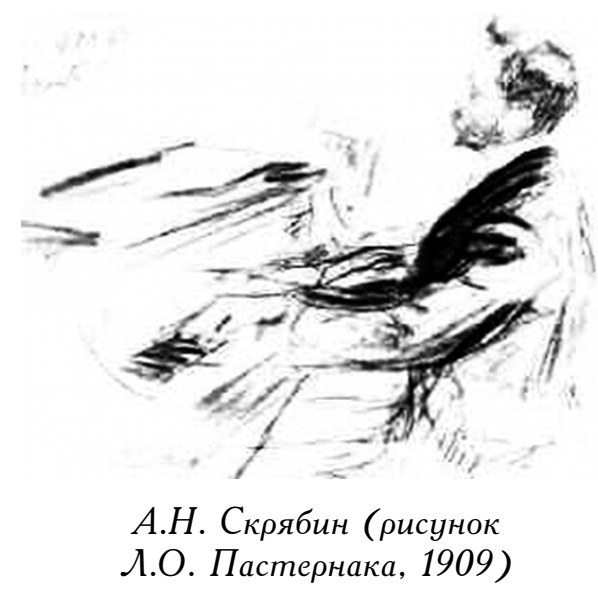

и ведущий к утомлению» [џит. по: 1, c. 146]. (В приведенном отклике удачно обрисованы исполнители «аполлонического»и «дионисийского» типов.)

Еше два пианистических антипода Рахманинов и Скрябин - привлекали внимание различием сџенического облика, обусловленного различием их художественных натур, образных миров, исполнительских приемов. Это внешнее различие, отражающее внутреннее, удачно запечатлено на рисунках ᄉ.О. Пастернака.

Знаменитая скрябинская манера «ласкать клавиши», использовать при игре движения рук и пальџев «из рояля» нашла отражение и в воспоминаниях современников. «В его игре, - писал А.А. Пастернак, отображалась и вся его одухотворенная легкость, столь для него характерная во всех проявлениях: в походке, наприме, в движениях, в жестикуляџии и вскидывании головы... ОН всегда сидел на несколько большем, 


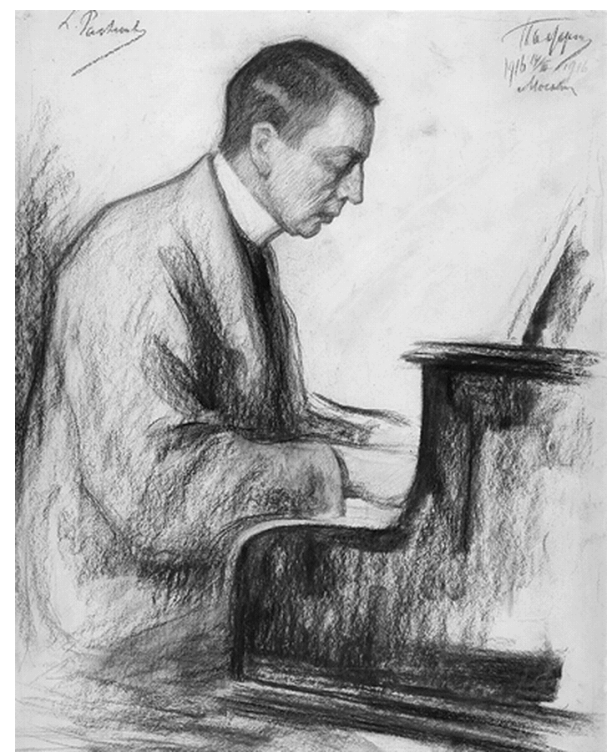

С.В. Рахманинов (рисунок А.О. Пастернака, 1918)

чем обычно, отстоянии от клавиатуры. Он сидел, откинув торс и вздернув голову. Вот тут-то и казалось, что пальџы его не падали на клавиатуру, а как бы порхали над ней» [22, с. 210].

Совсем иначе выглядел на сџене Рахманинов, о «материальном» интонировании которого Скрябин язвил: «В его звуке так много материи, мяса, прямо окорока какие-то...» [џит. по: 25, с. 220]. Рахманинов, в противоположность Скрябину, чаше нависал над клавиатурой (как и Антон Рубинштейн) и как бы, по собственным словам, «прорастал пальцами в клавиатуру». Музиџировавший с Рахманиновым в четыре руки А.ФD. Гедике описывая его манеру так: «Вслушиваясь в каждый звук, он как бы “проџупывал" исполняемое» $[9$, с. 9].
Различия ярко отражались и на лиџах двух артистов во время игры: современники отмечали каменное, сосредоточенное, практически неизменное выражение лиџа у Рахманинова и открытое, оживленное, изменчивое у Скрябина.

На своеобразный критерий в размежевании в прошлом внешних исполнительских манер обрашал внимание Л.И. Ройзман, отмечавший, что в первой четверти XIX столетия в России популярный среди интеллигенџии «Московский телеграф» указывал в разделе «Модные обычаи» разные формы поведения для исполнителейпрофессионалов и исполнителейлюбителей: «...Если певеџ или певиџа по ремеслу (то есть профессионалы. $\lambda$. $\rho$.) поет или играет, им можно сделать какое-нибудь выразительное телодвижение, напротив - девушка или мушина - неремесленники (то есть любители. $-\Lambda$. $\rho$.) должны быть неподвижны... какое бы страстное выражение не встречалось им в нотах» [24, c. 40$]$.

В наше время сохранилась обычная для исполнительского искусства полифония стилей, которая была и в XVIII, и в XIX веках. Об этом ярко говорит, в частности, феномен Вана Клиберна, вернее разная реакџия на ряд главных особенностей его искусства. Появившись в СССР в 1958 году, он оказался пришельџем из досоветского прошлого - русского (Рахманинов, 


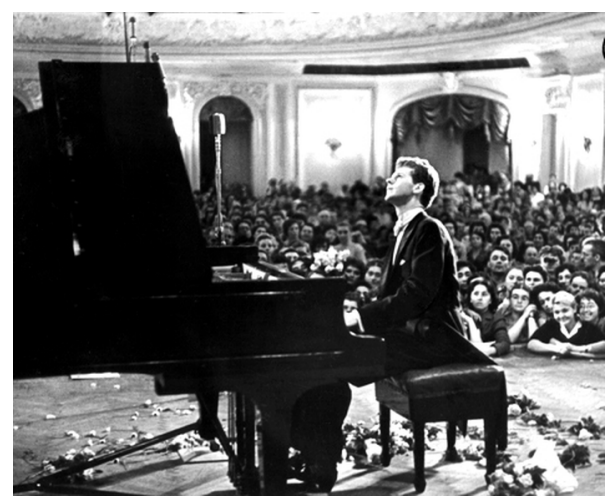

Ван Клиберн покорил московскую публику кониа 1950-х годов своей раскрепощенной исполнительской манерой

Шаляпин), да и европейского тоже (почему-то забывают, что 14 лет до Розины Левиной Клиберн занимался под руководством своей матери учениџы выдаюшегося листовского воспитанника Артура Фридгейма!). Пианист из США буквально обжег всех «неслыханной» (молодыми) и подзабытой («стариками») свободой лирического самовыражения. Не могу не вспомнить в связи с этим горестных признаний $\mathcal{\lambda . Н . ~ В л а с е н к о : ~ « Н а м ~}$ запрешали играть так раскрепошенно. Это считалось дурным вкусом».

Раскрепошенность Клиберна проявлялась и во внешнем поведении на сџене: он играл, часто не глядя на клавиатуру, широко жестикулируя, часто поднимая голову вверх и т. д. Благодаря такой непосредственности и искренности в жестикуляџии и мимике пианист дополнительно покорил многих слушателей. В связи с ролью пантомимического фактора в его искусстве показателен спор ․Н. Оборина (члена жюри) и А.Б. Гольденвейзера (ответственного секретаря того конкурса). Оборин, которому многое было не близко в Клиберне и который ставил ему сравнительно низкие оџенки, посетовал как-то в разговоре с Гольденвейзером, очевидно рассчитывая на близкую к своей реакџию: «Ну, почему Клиберн так развязно ведет себя за инструментом, почему он вскидывает руки, почему все время задирает голову!?» — «Левушка», ласково и снисходительно ответил мудрый старец, - «он не задирает голову, он говорит с Богом!»...

Вот насколько различаются взгляды по интересующей нас проблеме!

Показательно, что тот же Гольденвейзер, которого иногда излишне упрекают в сдержанности и даже сухости манеры игры, отмечал важность внешних проявлений пианиста за роялем и неоднократно говорил о необходимости находить степень соответствия пластики движений музыканта художественному образу исполняемого: «Играть нужно так, чтобы человек, отделенный от исполнителя звукопрониџаемой, но вместе с тем прозрачной перегородкой и только видяший (!) движения его рук, мог бы себе представить, конечно, не звуки, но характер той музыки, которую он играет» [7, с. 39].

Кстати, на том же конкурсе С.Т. Рихтер оџенил выступле- 
ние Клиберна высшими баллами и назвал его «музыкальным гением». Пантомимика молодого техасца придавала его музыкальному облику особое обаяние. Сам Рихтер держался на сџене удивительно артистично и поражал - помимо всего прочего пластикой сџенического поведения. Об этом ярко писал А.Н. Наумов, развивавший в своем творчестве близкий ему в этом отношении рихтеровский подход.

«Святослав Теофилович часто мне говорил, - отмечал Наумов, - что ненавидит, когда во время киноили телесъемки исполнения показывают его лиџо... "На лиџе отражена моя мучительная работа, - говорил он, а это не то, важен лишь результат". Он считал, что на конџерте нужно только слушать. Мне же как раз было интересно не только слушать, но и смотреть, наблюдать за ним, потому что лиџо отражает (!) такие таинственные переживания, которые руками и пальџами нельзя передать даже на самом хорошем рояле. Мне важна мимика. Она может иногда даже противоречить тому, что играют, или соответствовать, или дополнять, но равнодушного, отрешенного лиџа во время исполнения я не признаю. Лиџо Рихтера было поразительным. Помню одно исполнение финала «Аппассионаты» - никакая аудиозапись не может этого передать, это надо было видеть! Мимика

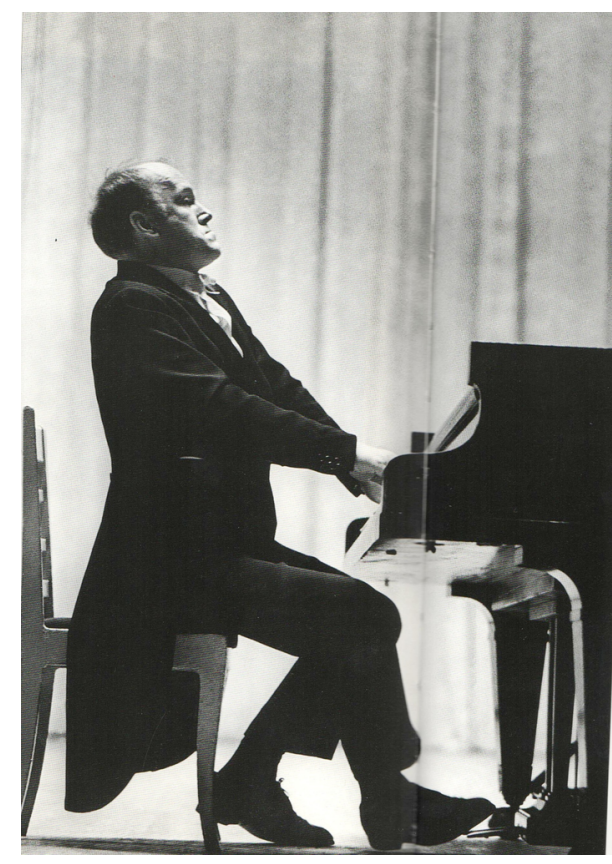

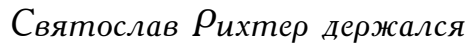
на сиене удивительно артистично, поражая пластикой сиенического поведения

Рихтера напоминала сџену из «Короля

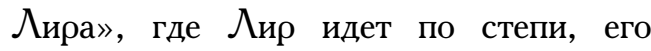
предали, а на его голову обрушиваются буря, молнии, гром, град, и он рвет на себе волосы. Само же исполнение оказалось столь простым... (везде выделено мною. - $A$. M.)» [19, с. 60].

Обратим внимание, что «само исполнение» (то есть исполнение вне внешнего, пантомимического, визуального воздействия) было, по впечатлению ᄉ.Н. Наумова, «очень простым» и едва ли бы вызвало столь богатые образные ассоџиаџии.

И от Нейгауза, и еще больше от Рихтера шла лигия, подхваченная 
и развитая А.Н. Наумовым. В дополнение к отмеченному приведем прониџательные слова его ученика А. Хитрука: «...Сушественным аспектом феномена Наумова-музыканта явилось то, что он... упорно и отчетливо расширял граниџы пианизма далеко за пределы собственно игры на фортепиано. Здесь в первую очередь хочется сказать о пластической составляющей, в рамках которой почти всегда мыслилась жизнь звука в педагогике Наумова. Это, конечно, было генетически связано с тенденџиями театрализации и визуализации, характерными для европейской инструментальной музыки, начиная с эпохи Дебюсси, Прокофьева и Стравинского. И отнюдь не секрет, что подобные тенденџии проникли в манеру музиџирования Льва Николаевича во многом под воздействием его кумира в исполнительстве - Святослава Рихтера» [30, c. $9-10]$.

О воздействии того же рода (не музыкальном, не пианистическом) в не меньшей степени свидетельствует и наблюдение М.В. Плетнева: «Рихтер это пианист, который обладал удивительным свойством. Он мог выйти на сџену и... уйти. И этого было вполне достаточно (к артистам такого рода можно отнести и самого Плетнева. - $A$. M.). Но что странно... потом слушаешь запись - что-то не то... За его музыкой что-то такое стояло. Нечто очень масштабное, как и вся его фигура, и вы- ход на сцену, и это лиџо с тевтонской челюстью» [џит. по: 27, с. 165].

Учитель $\rho_{\text {ихтера }- \text { Г.Г. Нейгауз }}$ сравнивал сџеническую пластику Рихтера и Станислава Нейгауза: «Первый “играет” всем телом, почти как актер, - конечно, совсем ненамеренно, - стихийно, так ему нужно, так хочется; второй - сидит как в старину сидели, предельно спокойно и “благородно", изредка только наклоняясь к клавиатуре для извлечения большого forte» [20, с. 90].

Эти показательные признания выдаюшихся музыкантов вызывают многочисленные мысли и ассоџиаџии.

Помню, как меня всегда поражала значительная разниџа в восприятии одного и того же выступления: либо только на слух, либо в видеозаписи. Одно впечатление - чаше всего очень среднее - было после прослушивания исполнителя из середины первого или из второго амфитеатра Большого зала консерватории. И совсем другое, - нередко гораздо более сильное, - когда по телевидению давали видеозапись: тут и само звучание было более выпуклым (поскольку микрофоны были рядом с инструментом), и визуальная сторона исполнения (частые крупные планы) значительно обогашала восприятие из зала, где рассмотреть (особенно издалека) детали пантомимики артиста просто невозможно.

Вспомнилась собственная давняя заметка, опубликованная еше в 1976 году 
в газете «Советская культура» в связи с показом по Џентральному телевидению записи выступления Э.Г. Гилельса. Охарактеризовав выдаюшиеся достоинства исполнения артистом ФФортепианного конџерта Шумана, автор отклика указал также: «Немалую роль играет и внешняя сторона исполнения - вопрос, которому обычно не придается серьезного значения... Мастерски используя пластику движениі, Гилельс проясняет тонкий ритмический рисунок шумановской «ткани», подчеркивает то плавность и текучесть, то взрывчатую силу высказывания». И далее в статье имеется важный комментарий: «Мы не случайно обратили внимание на это исполнительское средство. Оно воспринимается только тогда, когда слушатель находится в конџертном зале и зрительно наблюдает музыканта. Радио и грамзапись здесь бессильны. Зато роль телевидения, раздвигающего стены коншертных залов, трудно переоџенить» [16, с. 5]. Конечно, за прошедшие десятилетия в результате невиданного технического прогресса видеозаписи Гилельса (и других крупнейших артистов) стали несравненно доступнее любому меломану, но важно подчеркнуть, что и тогда и сегодня воспринимать игру мастера лучше комплексно - с учетом всех, в том числе и пантомимических компонентов. Шутливо и в стихах пишет по этому поводу Б.А. Печерскии: «Не хотел бы кого-нибудь обидеть, // Но игру пианиста надо видеть» [23, c. 39].
Вспомнился и рассказ одного из учеников Д.Ф. Ойстраха. Знаменитый скрипач, как и Рихтер, не любил свои теле- и видеозаписи: ему казалось, что все его движения и перемешения на сџене преувеличены (правда, сделать с собой что-либо он не мог). Этот же ученик Давида Федоровича (между прочим, народный артист России, профессор Московской консерватории) поведал, что не может слушать Хейфеца по видеозаписи: «Понимаете, слышишь у него какую-нибудь замечательно звучашую шемяшую фразу, а лиџо при этом абсолютно равнодушное и ничего не выражаюшее. Ну, как это можно совместить?! Это же совершенно уничтожает трагическое впечатление от прослушиваемого!». Тут невольно приходят на ум строки из статьи Шумана о манере поведения на сџене немеџких певиџ: «Прекрасное пение при мраморнонеподвижном лиџе заставляет усомниться - есть ли в этом искусстве внутреннее содержание» [33, с. 308]. О том же уже в наши дни писал С.Е. Фейнберг: «Вид артиста, безучастного к исполняемой музыке, деревянная неподвижность посадки пианиста, окаменевшее в ледяной неподвижности лиџо - все это мало способствует располагающему впечатлению» [28, с. 186-187].

Всплывает в памяти и наблюдение известного пианиста-педагога, историка пианизма Я.И. Мильштейна, кстати сказать, большого поклонника и близкого друга Рихтера: «В жестах 
выдаюшегося мастера, оправданных характером исполняемого, подчас отражаются самые глубокие (!) душевные переживания» $[18$, с. 131].

Об огромной силе зрительных впечатлений слушателя при восприятии игры исполнителя красноречиво свидетельствуют оригинальные научные эксперименты, проведенные ‥ ․ Бочкаревым. Исследователь, пользуясь сугубо научным языком, изучал «эффект влияния внешне выраженных форм эмоциональной экспрессии музыканта-исполнителя на адекватность восприятия слушателями композиторского замысла» [см.: 5, с. 127-136]. С этой целью одна и та же звукозапись Ноктюрна c-moll Шопена (исполнение М.С. Воскресенского) была наложена экспериментатором на видеозаписи двух других пианистов, игравших по заданию исследователя по-разному: один, максимально усиливая внешнее выражение положительных эмоџий (просветленность, благородство, возвышенность), другой - заостряя средствами мимики и пантомимики отриџательные эмоџии (грусть, отчаянье, скорбь). При монтаже исходной фонограммы с видеозаписями обеспечивалась полная синхронность соединения зрительного и слухового рядов.

Поразительно, что практически все испытуемые (а это около 100 человек - студенты консерватории и педагоги музыкальных училищ), слушая одну и ту же звукозапись (но совмешенную с разными видеоверсиями и разными вариантами внешней экспрессии), отметили, что слышат разные интерпретации и находят в каждой из них разнье чертьь! Удивительно: фонограмма одна и та же, но, благодаря воздействию разных проявлений мимики и жестикуляџии, слушатели, судя по их письменным самоотчетам, ощушают и разный темп, и разную динамику, и разную фразировку, и разные тембры, и разное образное содержание! В какой-то одной из двух записей испытуемые (из-за воздействия одних визуальных факторов) ощушают реально не сушествуюшие погрешности в педализаџии, артикуляџии, нюансировке, регистровой драматургии, интонировании; в другой (благодаря влиянию иных зрительных впечатлений) - они этих погрешностей не слышат и отмечают только достоинства, но ведь звукозапись-то в обоих случаях абсолютно одна и та же! Вот что значит различный видеоряд!

Интересны и следующие наблюдения экспериментатора: «B интерпретаџиях исполнителя с интенсивными внешними формами әкспрессии испытуемые услышали гораздо больше нюансов, оттенков эмоџий. Однако менее яркая, менее динамичная экспрессия другого исполнителя позволила слушателям глубже погрузиться в музыку».

Выводы исследователя очевидны: «Степень интенсивности внешнего вы- 
ражения эмоџий значительно влияет на оџенку эмоџионального содержания музыки... Экспрессия исполнителя, его жесты, поведение, внешняя эмоџиональная выразительность и зарази- тельность интерпретаџии значительно может повлиять на проџесс музыкальной коммуникаџии».

Здесь мы уже входим в область теории фортепианной игры.

\section{ЛИТЕРАТУРА}

1. Айзенштадт С. Учитель музыки. Жизнь и творчество Карла Черни. М.: Композитор, 2010. 216 с.

2. Алексеев $A$. Из истории фортепианной педагогики. Руководство по игре на клавишно-струнных инструментах (от эпохи Возрождения до середины XIX века). Хрестоматия. Киев: Музична Украина, 1974. 166 с.

3. Алексеев $A$. История фортепианного искусства: учебник для муз. вузов в трех частях. Ч. 2. М.: Музыка, 1967. 288 с.

4. Бёрни Ч. Музыкальные путешествия. Дневник путешествия 1772 г. по Бельгии, Австрии, Чехии, Германии и Голландии / Пер. Е.М. Алексеевой и В.Г. Вилюмана. М.; Л.: Музыка, 1967. 291 с.

5. Бочкарев $A$. Психология музыкальной деятельности. М.: Классика-XXI, 2006. $352 \mathrm{c}$.

6. Будяковский Л. Ференџ Лист. Пианист. Педагог. СПб.: Композитор, 2012. 124 с.

7. В классе Гольденвейзера: Сб. ст. / Сост. Д.Д. Благой, Е.И. Гольденвейзер. М.: Музыка, 1986. 216 с.

8. Вик $C D$. Сортепиано и пение (избранные главы) / Пер. и прим. Н.А. Шохиревой // От барокко к романтизму. Музыкальные эпохи и стили: эстетика, поэтика, исполнительская интерпретаџия. Вып. 3 / Отв. ред. С.В. Грохотов. М.: Научно-издательский центр «Московская консерватория», 2012. С. 260-271.

9. Гедике $A$. Памятные встречи // Воспоминания о Рахманинове в 2-х томах. 5-е. изд. Т. 2 / Сост. З.А. Апетян. М.: Музыка, 1988. С. 4-18.

10. Гейне Г. Аютеџия / Пер. А. Федорова // Гейне Г. Собр. соч. в шести томах. Том 6. Проза 40-х - 50-х годов. Письма. М.: Художественная литература, 1983. C. 5-279.

11. Дюбюк $A$. Из воспоминаний о музыкальной жизни старой Москвы // Алексеев $A$. Русские пианисты. Очерки и материалы по истории пианизма / Под ред. А.А. Николаева. М.; Л.: Музгиз, 1948. С. 110-117.

12. История скрипичного искусства: Учебник: В 3-х вып. Вып. 1 / ‥ Гинзбург, В. Григорьев. М.: Музыка, 1990. 285 с.

13. Куперен $Ф$. Искусство игры на клавесине /Пер. О.А. Серовой-Хортик. М.: Музыка, 1973. 152 с.

14. Аевашева О. Ференц Лист: Молодые годы. М.: Музыка, 1998. 334 с.

15. Лист ФD. Ф. Шопен. 2-е изд. / Пер. и прим. С.А. Семеновского; Обш. ред. и вступ. ст. Я.И. Мильштейна. М.: Музгиз, 1956. 432 с.

16. Меркулов $A$. Не только в юбилей // «Советская культура», 1976, 10 декабря [Переизд.: Волгоград - фортепиано - 2012: Сб. ст. и материалов по истории и теории 
фортепианного искусства / Ред.-сост. М.В. Лидский. Волгоград: ПринТерра-Дизайн, 2012. C. 14].

17. Мильштейн Я. Аист. Изд. 2-е, расширенное и дополненное. Т. II. М.: Музыка, 1971. 600 c.

18. Мильитейн Я. Статьи, воспоминания, материалы / Сост. Е. Калинковиџкая, С. Мильштейн. М.: Сов. композитор, 1990. - 288 с.

19. Наумов $\mathcal{1}$. Под знаком Нейгауза. Беседы с Катериной Замоториной. М.: РАФ «Антиква», 2002. 329 с.

20. Нейгауз $Г$. К чему я стремился как музыкант-педагог. К столетию Московской консерватории // Нейгауз Г. Размышления, воспоминания, дневники. Избранные статьи. Письма к оодителям. М.: Сов. композитор, 1975. С. 84-109.

21. Нейzауз Г. Пианист Артуро Бенедетти Микеланджели // Нейгауз $Г$. Размышления, воспоминания, дневники. Избранные статьи. Письма к родителям. М.: Сов. композитор, 1975. С. 296-298.

22. Пастернак А. Лето 1903 г. // Новый мир. 1972. № 1. С. 203-211.

23. Печерский Б. Ритмы и рифмы. Афоризмы и афоризки. М.: Композитор, 2012. $120 \mathrm{c}$.

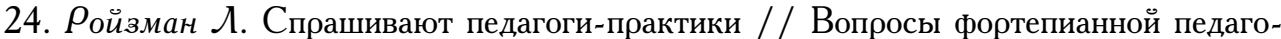
гики / Общ. ред. В.А. Натансона. М.: Музгиз, 1963. С. 21-46.

25. Сабанеев Л. Воспоминания о Скрябине. М.: Классика-XXI, 2000. 391 с.

26. Савшинский С. Пианист и его работа. М.: Классика-XXI, 2002. 244 с.

27. Токарева $\mathcal{\lambda}$. Музыкальные открытия Михаила Плетнева. Этюды, наброски, интервью. М.: Известия, 2009. 264 с.

28. Фейнберг С. Пианизм как искусство. 2-е изд., доп. М.: Музыка, 1969. 599 с.

29. Фришер Э. Фортепианные сонаты Бетховена // Исполнительское искусство зарубежных стран / Сост. и ред. Я. Мильштейн; Пер. с нем. ․С. Товалевой. Вып. 8. М.: Музыка, 1977. С. 215-217.

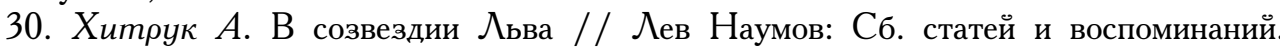
М.: Дека-ВС, 2007. С. 8-12.

31. Шыпин Г. Музыкант и его работа: Проблемы психологии творчества. М.: Сов. композитор, 1988. 384 с.

32. Шонберг Г. Великие пианисты / Пер. В. Бронгулеева. М.: Аграф, 2003. 416 с.

33. Шуман $\rho$. Избранные статьи о музыке / Ред., вступ. ст. и примеч. Д.В. Житомирского. М.: Музгиз, 1956. 400 с.

34. Шуман $\rho$. О музыке и музыкантах: Собр. ст. в двух томах. Т. II-A / Сост., ред., коммент. Д.В. Житомирского; Пер. А.Г. Габричевского и А.С. Товалевой. М.: Музыка, 1978. 327 с.

35. Шуман Р. Письма (1817-1840): В 2-х т. / Сост., текстологич. ред., вступит. ст., коммент, указатели Д.В. Житомирского. Т. 1. М.: Музыка, 1970. - 632 с.

36. Marpurg F. W. Historisch-kritische Beiträge zur Aufnahme der Musik. Bd. III. Berlin, 1756. $235 \mathrm{~S}$.

\section{(Продолжение следует)}

